\title{
SEXUAL MATURATION IN ADOLESCENTS FROM THE REGION OF EASTERN RODOPI IN CONNECTION WITH THEIR SOCIAL ENVIRONMENT
}

\author{
Slavi Tineshev ${ }^{1}$, Georgi Tomov ${ }^{2}$, Ivan Dimov ${ }^{1}$, Emilia Andreenko ${ }^{1}$, Atanas Baltadjiev ${ }^{3}$ \\ ${ }^{1}$ Department of Human Anatomy and Physiology, Faculty of Biology, \\ University of Plovdiv, "Paisii Hilendarski", Bulgaria \\ ${ }^{2}$ Oral Pathology Department, Faculty of Dental Medicine, Medical University, Plovdiv, Bulgaria \\ ${ }^{3}$ Medical University Plovdiv, Department of Anatomy, Histology and Embryology, Bulgaria
}

\begin{abstract}
Summary. The purpose of this paper is to characterize the influence of socio-economic environment on the processes of sexual maturation and the age of adolescent's menarche from the Eastern Rhodopi. Subjects of study are 1378 children and adolescents from local schools in Ivaylovgrad, Svilengrad and Lyubimets. These are 730 girls and 648 boys aged 8 to 17 years. In connection with studying the influence of environmental factors on the sexual maturation processes, interviews with parents were conducted. The survey contains 22 questions with parents' data, which were used to clarify the social, economic and professional status, living conditions of family life, etc. The results show that although genetically determinated, the processes of sexual maturation are significantly influenced by exogenous factors, and in a peculiar way they reflect the specific social and economic situation in a given geographical area at a randomly selected time period.
\end{abstract}

Key words: sexual maturation, socio-economic factors, menarche.

\section{Introduction}

Puberty apart from its genetic determination is largely influenced by a number of exogenous factors (Година, Миклашевская, 1989; Година, Задорожная, 1995; Николова, Петров, 1979). However, the order of appearance of different pubertal events in different human populations is always the same. This pattern is species-specific in humans, occurred in the course of evolution, under the influence of different socio-cultures (Стоев, и др, 1987, 1988). It should be borne in mind that these external environmental factors vary in the different regions of the country, which also determines the differences in the nature of the process of maturation of one or another group of people (Юрко, Веремкович, Силина, 1984). This motivated us to undertake a regional study on the processes of sexual maturation in the young generation and to consider the influence of the specific social environment.

\section{Material and methods}

Subjects of study are 1378 children and adolescents from local schools in Ivaylovgrad, Svilengrad and Lyubimets. These are 730 girls and 648 boys aged 8 to 17 years. Contingent is divided into eight one-year age groups.

Autor za korespondenciju: Slavi Tineshev, e-mail: stineshev@abv.bg Department of Human Anatomy and Physiology, Faculty of Biology, University of Plovdiv, "Paisii Hilendarski", Bulgaria 
We reported scopically, by the methodology of Shtefko-Ostrovskiy (1929), the most common in practice secondary sex characteristics that pass through different stages of development. The age of onset of first menstruation is reported using the method "status quo" (Gavrilovic, 1979., Danker-Nopfe, 1986) or retrospectively. The method is based on the presence or absence of menstruation in a girl.

In connection with studying the influence of environmental factors on the sexual maturation processes, interviews with parents were conducted . The survey contains 22 questions with parents' data, which were used to clarify the social, economic and professional status, living conditions of family life, etc.

The material was processed using the statistical package "STATISTICA 6.0".

\section{Results and discussion}

Our results showed that, although not directly, but significant role in the onset of pubertal events play various socio-economic factors such as education level of parents, family income, sequence of births, etc.. To explain this effect we examined the family environment of students, based on 1042 parents' answers from the survey questionnaires, given back to us. This represents $75.61 \%$ of the total number of children studied. This percentage is high enough for the analysis and interpretation of the influence of environmental factors on the process of sexual maturation. On one hand, we can assume that the ungiven-back surveys increase the share of families with low educational level of parents, and, on the other hand, the families whose financial situation is very different from the average (positive or negative direction). Thus, our analysis excluded children from families of extreme social status .

Results showed that the average ages of development of the secondary sexual characteristics, as well as their sequence of occurrence, in both sexes, are hardly influenced by the social environment, which is also confirmed by the literature data.

In contrast, the average age of menarche was particularly sensitive to exogenous factors, so we will pay special attention to it. According to several authors, the most sensitive indicator of environmental conditions is the average age of onset of first menstruation.

The dependence of menarche on the educational level of parents (Figure 1) showed that with increasing father's and mother's educational level we observed lowering of the average age.

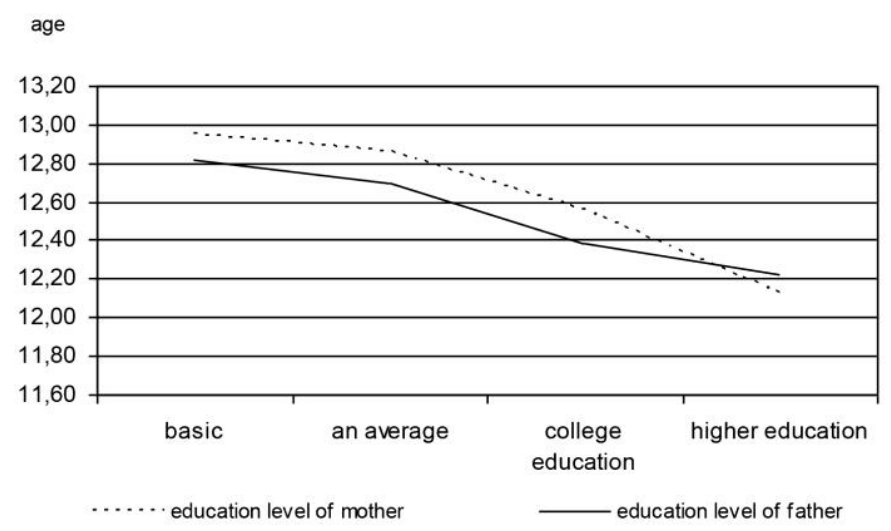

Figure 1. Mean age at onset of menarche depending on the level of education of parents. 
The first menarche in daughters of parents with primary education occurs about 8-9 months later than in girls at their age, whose parents have college or university education. It turned out that the educational level of a mother has a more significant influence on menarche age than that of a father. The lowest age of first menstruation was observed in girls whose mothers are graduates - 12.12.

Income per a family member was also crucial in terms of the average age of menarche (Figure 2). We assumed the amount of BGN 300 as average income per a family member (Study conducted in 2009, and during this period the amount of BGN 300 is identifiable with today's economic conditions). Income of up to 500 BGN we considered above average standard of living, and income above 500 BGN we accepted as higher living standards. For income under $3001 v$ we thought that the family has a low economic standard. Our expectations are also confirmed by the literature data. Income per family member is the inverse of the average age of menarche. With rising income per family member the average age of onset of first menstruation decreases. This can be explained by the higher living standards of families with high-quality and low-calorie balanced diet, with opportunities for diverse sports activities, etc. The chart shows that the daughters of families living on less than BGN 300 per family member menarhe occurred later -12.98 .For girls living in families with high and very high living standards (up to and exceeding 500 BGN) social differences in early menstruate were observed.



Figure 2. Mean age at onset of menarche depending on the income of the family member.

The educational level of parents is in a very high correlation with income per family member $(r=0.87)$. Highly educated parents tend to have better career opportunities, and higher monthly income per family member. This is probably one of the most important prerequisites for reducing the average age of first menstruation. Usually the level of family life depends on the number of members in it and on the number and order of births of children, which largely influences the onset of menstruation in girls. As seen from the Figure 3 the average age of first-born daughters' menarhe is 12.96 years.

The trend is to lower the average age with increasing sequence of births, as in our study it was observed up to the third-born girls. For girls who were born fourth in a family the age of first menstruation increases again approaching the second-born daughters'. Usually, families with more than three kids, parents are less educated, respectively, income per family member is lower, which explains the increase in the average age of menarche in daughters who were fourth-born. 


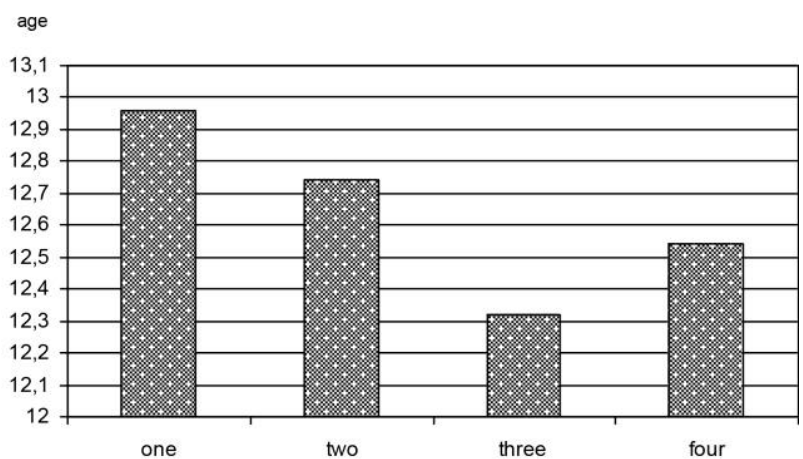

Figure 3. Mean age at onset of menarche depending on the number of childrens in family.

Comparing the family environments of the surveyed students from the Eastern Rhodopi (this study), the Central Rhodopi area (District Smolyan, Mladenova; 2003; Stoev, 2006) and Plovdiv region (Nikolova, 2008) showed that adolescents from Smolyan are often children of parents with lower education levels (over $70 \%$ are parents with secondary education) and professional status. Large families with low and middle income per family member dominate. Children are raised in a bit conservative social atmosphere. It would be a factor for later sexual maturation in them, which is supported by the higher average age of menarche - 12 years and $9 \mathrm{~m}$. Youngsters from Plovdiv live in an entirely different family environment, which is a prerequisite for reducing the average age by about $3-4 \mathrm{~m}-12$ years and 6 months. families with one or two children are more. Parents have a high level of education and higher family income per family member (over 38\% of parents with higher education). Children have the opportunity daily to participate in various sports events. Family environment of children from the Eastern Rhodopi is not significantly different from that of Plovdiv region, as far as the number of families, education of parents and family income. The difference is mainly in the way of securing and maintaining the standard of living. If the parents of children from Plovdiv that are mainly engaged in the sphere of economy, banking, crafts, etc., the manner of maintaining the standard of living in towns Svilengrad, Liubimetz and Ivaylovgrad is mainly through agriculture and livestock i.e. in the field of agriculture. Menarche average age of the girls in this region is 12 years and $3 \mathrm{~m}$, which is probably due to extended processes taking place at the end of the first decade of the twenty-first century.

\section{Conclusions}

The average age of menarche in girls, depending on socio-economic factors, showed a positive relationship with educational status of parents, number of children in the family and order of birth and income per family member. Our study confirms data from a number of authors that the earlier average age of menarche is the prerogative of a higher socioeconomic status. In conclusion we can say that although genetically determinated, the processes of sexual maturation are significantly influenced by exogenous factors, and in a peculiar way they reflect the specific social and economic situation in a given geographical area at a randomly selected time period. 


\title{
References
}

Година Е.3., Миклашевская Н.Н. Экология и рост: влияние факторов окружающей среды на процессы роста и полового созревания человека. Рост и развитие детей и подростков. Итоги науки и техники. Сер. Антропология, т. 3., М., ВИНИТИ, 1989, с. 77-134.

Година Е.З., Задорожная Л.В. Сезонность менархе: биосоциальные аспекты. Вопр. Антропол, 1995, Вып. 88, с. 20-38.

М. Николова, И. Петров. Взаимоотношения между пубертет, степей на начална телесна височина и растеж на крайниците при деца от 7 до 22 години. Науч. тр. ПУ "П. Хилендарски", 17, 1979, № 4, с. 263-283.

Стоев, Р. и др. Менархе и семейно-битови фактори (изследвания при учащи в град София и град Смолян). - В: Човекът в условията на научно-техническата революция. Пловдив, 1987, Съюз на науч. раб. в България, клон Пловдив.

Стоев, Р. и др. Възраст при менархе и никои специфични за човека екологични фактори при студентки в град София. Младежка научна конференция по екологичните проблеми, Враца, 1-2 декември 1988, с. 151-156.

Юрко Г.П., Веремкович Л.В., Силина О.В. Критерии оценки влияния некоторых факторов среды на организм детей дошкольного возраста. Гигиенические аспекты охраны здоровья детей и подростков. Москва, 1984, с. 11-12.

Младенова, С. Антропологична характеристика на растежа и развитието та деца и подрастващи от Смолянски регион в съвременните условия на живот. 2003. Авт. Пловдив, 1-58.

Стоев Р. Антропологична характеристика на подрастващи - физическо развитие и полово съзряване във връзка със семейно-битовите условия. 2006. Дис трут, София, 1-140.

Николова М. Сборник от таблични и графични данни за растежа и развитието на пловдивски деца и подрастващи. 2008, 125-132.

\section{SEKSUALNA ZRELOST ADOLESCENATA IZ OBLASTI ISTOČNOG RODOPIJA VEZANA ZA NJIHOVU DRUŠTVENU SREDINU}

\author{
Slavi Tineshev, Georgi Tomov, Ivan Dimov, Emilia Andreenko, Atanas Baltadjiev
}

Sažetak.

\begin{abstract}
Cilj ovog rada je da okarakteriše uticaj društveno-ekonomske sredine na proces seksualnog sazrevanja kao i nastupanje prve menarhe kod adolescenata iz istočnog Rodopija. Uzorkom je obuhvaćeno 1378 dece i adolescenata iz lokalnih škola u Ivajlovgradu, Svilengradu i Ljubimeca. Od toga, 730 devojčica i 648 dečaka, uzrasta od 8 do 17 godina. Obavljeni su i intervjui sa roditeljima vezano za ispitivanje uticaja sredine na proces seksualnog sazrevanja. Upitnik sadrži 22 pitanja sa podacima roditelja koji su upotrebljeni kako bi se dobio uvid u društveni, ekonomski i profesionalni status, životne uslove u porodici, itd. Rezultati ukazuju na to da je, iako genetski uslovljen, proces seksualnog sazrevanja pod velikim uticajem egzogenih faktora, koji na poseban način reflektuju specifičnu društvenu i ekonomsku situaciju određene geografske oblasti u proizvoljno izabranom vremenskom periodu.
\end{abstract}

Ključne reči: seksualna zrelost, društveno-ekonomski faktori, menarha 